\title{
Race and Materiality in African Religious Contexts
}

\author{
Federico G. Settler \\ settler@ukzn.ac.za
}

\section{Abstract}

This article intends to explore the various approaches to materiality and religion that have been used in the study of religions in Africa, and in South Africa in particular. It explores recent scholarship on materiality and religion advanced by David Morgan (2012) as well as Dick Houtman and Birgit Meyer (2012), and then turn to David Chidester (2018), with some attention to Johan Strijdom (2014) to examine the framing of the debate in the Southern African context. The aim is to point out specific ways in which religion scholars privilege materiality of visuality, space, and ritual studies, at the expense of other ways of knowing and being. The article then advances some suggestions as to why or how these regimes are sustained and point out some problematics.

It examines the use of everyday material objects in new religious movements in South Africa and interrogate their contested reception. The article moves to unpack how contemporary debates about the indigenous and new religious movements or cults in South Africa represent conflicts on what 'things' may possess sacred qualities and how they may be endowed with religious authority. In this regard, the article will focus on the taxonomies and afterlife of things in the work of Arjun Appadurai $(1988,2006)$ and its location in relation to the black body, to explore how black bodies are scripted and imagined in relation to material religion. Finally, it raises some questions on how local debates about religion and materiality - with respect to the embodied and things - represent not just disruptions over what constitute religion, but also about how contests over the use of everyday objects signal the emergence of indigenous ways of knowing and being in African religious contexts.

Keywords: race, materiality, things, body, senses 


\section{Introduction}

Since 2014, the events, rituals, and claims from a number of new religious or Christian movements have captured the interest of the government and the media in South Africa and beyond. Among these captivating reports is one of Pastor Lesego Daniel of Rabboni Centre Ministries who reportedly instructed his congregations to eat grass in early 2014 (News24 2014). It was reported in several national newspapers as well as in the UK-based Daily Mail, that 'Pastor Daniel, who is based in Garankuwa, north of Pretoria, told dozens of followers to eat grass because "it will bring them closer to God"' (Thornhill 2014). Later in the same year it was reported that the pastor who had previously used congregants as a human carpet, in October 2014 convinced his church members to drink petrol (Thornhill 2014). His particular brand of religiosity was echoed in the ministries of others such as Prophet Penuel Mnguni of the End Times Disciples Ministries in Soshanguve, Pretoria, who claimed that he turned rocks into bread and snakes into chocolate, before he fed it to his congregation (Maluleke 2015). Solomon Kgatle (2017) notes that Pastor Lethebo Rabalago, a protégé of Pastor Daniel, reportedly sprayed his congregants with Doom (an insecticide) in 2016, to demonstrate the protective power of the gospel and to cure them from ailments. Pastor Paseka Motsoeneng, also known as Pastor Mboro, of the Incredible Happening Ministry, not only offers the regular array of healing practices, but claims to hold special powers to heal infertility in women through placing his foot on them, and in 2016, he offered (for sale) pictures of himself having gone to heaven during an Easter church service.

Kgatle (2017:3 of 8), drawing on the work of Van den Toren (2015), notes that 'neo-Pentecostals take the power of amulets and fetishes with utter seriousness - and consequently reject them - but also provide alternatives in the forms of anointing oil, blessed water, calendars or handkerchiefs'. With their Pentecostal interest in healing, possession, and miracles, Kgatle (2017:3 of 8) suggests that their "movement of manifestations took different directions and acts of "miracles" further by bringing some extreme manifestations that have left the African Christian Church in wonderment'. Tenyiko Maluleke (2014) suggests that, despite one's feelings about the ethics of the claims, these acts are symbolic gestures concerned with access to God or having an experience of the sacred.

In response to the allegations of abuse and exploitation of belief including the use of stones, leather belts, feeding rodents and snakes to 


\section{Federico G. Settler}

congregants, locking someone in a deep freezer, and driving over congregants - Pastor Rabalago, in an interview with a South African tabloid, Daily Sun, confirms that, for him, there is nothing special about Doom, except that he was instructed by the Holy Spirit to use it, and he asserts: 'I use everything that the Lord directs me to use to heal people’ (Molobi 2017).

This period saw a necessary response from government and religious authorities through an inquiry by the Commission of Religious, Linguistic and Cultural Minorities (CRL), that led to their report on the Commercialisation of religion and abuse of people's beliefs systems (CRL Rights Commission 2017). In addition to the sensational reports by the media, cited above, the Commission also notes other examples: 'Blessed water and oils are sold to congregants at a high marked-up price' and 'T-shirts, towels, and Vaseline are sold to congregants for good luck' (CRL Rights Commission 2017:31). The purpose of drawing the attention to these events and reports is not to contest the merits of the claims, but to highlight the fact that much of the legal and theological debates are framed by the use of everyday things for religious purposes, or religious objects for social improvement. While the public debate represents the contestations over ecclesial boundaries and authority, the use of everyday objects in these African religious contexts represents the various ways that religious authority is initially manufactured and fought over on a local level. I want to argue that the sale of prayer towels, blessed water and oils, or the use of grass, fridges, snakes, and heavenly pictures, all predate the public debates about freedom of religion and exploitation of people's beliefs. In the opening pages of his book, Religion: Material dynamics, David Chidester writes that the sacred is concerned with the 'making, ordering and circulating of religious things' (Chidester 2018:xii), and therefore I contend that these new religious communities and leaders are already engaged in processes of making and circulating religious things, and are now entangled in a contest over the ordering of these religious things. Chidester further suggests that 'the study of material religion can retain the term (religion) to signal a terrain in which human beings engage in meaningful and powerful ways with the material constraints and animations of matter, the interplay of sacralising and desecrating' as a way to not simply focus on religion but on the material conditions for negotiating the human (Chidester 2018:2-3).

It would be disingenuous to suggest that the contestation about religious practice and authority, and what constitutes religions, has not often been coupled with the believers' relationship to, and conceptions of the 
material. While these recent events and contestations over the use of everyday objects and animals in religious rituals have captured the public imagination and media interests, the influence of objects on religious life - whether in worship, diagnostic or interpretive practices - is not new and has a long history in Southern Africa. A survey of Chidester's work offers a particularly illuminating insights into the entanglement of religion with the material. I will cover some of his books that I consider most relevant for the argument that I seek to make in this article, with its focus on race, religion, and materiality in South Africa. This is not an exhaustive treatment of religion and materiality in the work of Chidester, as it does not incorporate his work that deals with the religion and popular culture in North American contexts. While Chidester (2000:378) argues that we ought to move beyond the focus on material objects to engage a political economy of the sacred through interrogating the 'material conditions, forces, and relations', I suggest that in Southern Africa, such conditions, forces, and relations are so historically entangled with racial schemas, that taxonomies of the sacred are invariably contested over what objects or things come to be regarded as sacred and religious, or not.

\section{The material in Chidester's work}

In his 1991 publication, Shots in the streets, Chidester discusses religion and materiality in the African religious context, by taking a look at the use of imphepho (the wild sage or liquorice plant used as a ritual incense for invoking the ancestors) and sacred oils as ancestral protection for fighters of the Pan African Congress in their armed struggle against the apartheid government. In his award-winning Savage systems (Chidester 1996) - essentially an archaeology of religion in the South African colonial frontier - Chidester explores the discovery of a ship's anchor near the Keiskamma River around 1800 , as an object or artefact through which protestants and the indigenous Xhosa made claims about the sacred. For the colonial observers in Savage systems, the Xhosa's superstition relates to the dead and the anchor serves as evidence that the indigenous people lack religion (Chidester 1996:76), thus producing a speculative contest over what constitutes religion. While the indigenous people approached the anchor (this object and thing), with respect and awe, for the missionaries and travelers the 'anchor stood as a monument 


\section{Federico G. Settler}

to the lack of religion among the indigenous people' (Chidester 1996:86). Chidester is not unique in suggesting that conceptions of religion are mediated through its entanglement with the material at the colonial frontier. In terms of the colonial frontier, one might be able to extrapolate how various local or colonial objects, such as masks, fabric, spices, and soap have been embroiled in making and marking the imperial boundaries between savage, superstition, and religion (cf. McClintock 1995; Sweet 2002; Lincoln 2014).

This essay on the material manifestations of religion on the colonial frontier of Southern Africa is an extension of Chidester's earlier work on popular religion in the United States, where he uses other registers such as baseball, Tupperware, and Coca-Cola to explicate American ways of knowing and being religious. In the Southern African religious context, several strands of Chidester's reflection on materiality and religion converge in his 2012 publication, Wild religion, where he brings together his earlier work on Credo Mutwa, the Zulu self-declared religious authority, and his sensory incorporation of everyday objects, of plants, and the environment to construct and explain a particular brand of indigenous religion. Wild religion also incorporates praise singing by imbongi, Zolani Mkiva, at the inauguration of President Nelson Mandela in April 1994 on the one hand, and the opening of the Football World Cup in June 2010 on the other, drawing attention to the sensory system in African traditional religion. Chidester's exploration of objects and making of religion in Southern Africa culminate with the invocation of the vuvuzela - a replica of the traditional kudu-horn used during the indigenous religious ceremonies but commercialized for the 2010 Football World Cup fan cultures. He states that this sacred sound and noisy instrument represent indigenous sacrality, thus pushing back against colonial denigration of African cultures and religion (Chidester 2012:185). Duane Jethro (2014:180) asserts that vuvuzelas emerged as 'material objects cast as heritage through sacralising practices that distinguished them as legitimate registers of the past for the "hailing" of collective identities'. Therefore, through drawing on both registers of the indigenous and contemporary narratives of nation building, these objects became central to the 'inevitable contestation over ownership of the means, modes and forces of producing the sacred' (Chidester 2012:5).

While Chidester, in the above texts as well as in his book, Religion: Material dynamics (Chidester 2018) offers a well-articulated and variegated analysis of how the material plays out in colonial and postcolonial South 
Africa, he is not unique in trying to explain contemporary South Africa through using registers of the material. Jacob Dlamini, for example, in his book, Native nostalgia (Dlamini 2009), reflects on the post-apartheid social world through an exploration of the senses, and he variously offers sensory nostalgia for the smell of township smoke that signifies home, the social life of rats (Dlamini 2009:66), the weight and texture of money as indicative of it having value (Dlamini 2009:98), and the grainy 1980s television that evokes familial intimacies (Dlamini 2009:27) - all in an attempt to 'upset the neat master narrative of the struggle in which blacks suffered and struggled the same' (Dlamini 2009:67). In his exploration of sight, sound, and smell, Dlamini eloquently explains how, for example, the presence of rats around townships symbolize plenty of food. Similarly, Kerry Chance, in her book, Living politics in South Africa's urban shacklands, draws on the elements, earth, water, fire, and air, to reflect and account for the feeling of discontent among black South Africans during the post-apartheid period. She notes that 'where there is fire, there is politics' (Chance 2018:25ff). Both Dlamini and Chance, like Chidester, disrupt the registers of the material that one might be inclined to draw on to explain what contemporary South Africans hold dear, whether through nostalgic reminiscence or discontent and protest. What is evident from their respective framings and analyses of social and religious worlds in South Africa, is that traditional taxonomies and explanations fail to fully account for the complex ways in which contestation over meaning plays out. In accounting for the persistent contestations over what is regarded as sacred, Chidester argues that the sacred 'is produced through the labor of intensive interpretation and regular ritualization, which generates surplus meaning that is immediately available for appropriation, as people make the sacred their own, but is also vulnerable to contestations over who legitimately own and operates the sacred' (Chidester 2012:ix).

\section{Materiality and religion}

Strijdom (2014:1 of 7) suggests that 'material religion' constitutes a new way to reflect on the study of religion. He takes Houtman and Meyer (2012) as a point of departure to illustrate how material religion is primarily concerned with objects and spaces, as well as feelings and the senses (Strijdom 2014:1 of 


\section{Federico G. Settler}

7). He goes on to argue that the 'material turn in Religious Studies should not stop with the recognition that the sacred is necessarily present in concrete things in the world, but that it would still crucially need critical theory to assess the political, social and economic uses of these objects in religions' (Strijdom 2014:2 of 7).

The second useful contribution from Strijdom's article is his discussion of the assertion of Houtman and Meyer that such terms as totem, idol, and fetish do not simply refer to 'distinct types of material objects but rather to particular human attitudes toward and modes of using "things" (Houtman \& Meyer 2012:14). In the end, Strijdom invites postcolonial scholars to engage the material as an analytical category about what constitutes religion, and he suggests that the material promises to offer new ways to interpret contemporary African religion and religious practice.

Generally, religion scholars regard material religion, or the material turn in religious studies, as the shift from ritual studies and the study of religion's preoccupation with institutions, beliefs, and practices, as well as religious actors' engagement with it. In this article, I argue that the material turn in religion also marks the shift from institutional religion to the everyday religion - mundane routines and practices related to religion or religious beliefs enacted in the course of everyday life. Some scholars suggest that the very idea of what constitutes materiality should be interrogated in relation to immateriality (Barad 2007; Braidotti 2002), while others prefer to use such terms as 'materializing' with the view to privilege a more affect-centered approach to religion and materiality (Meyer 2008).

The widely used assertion of Meyer, Morgan, Paine, and Plate (2010:209) is that 'a materialized study of religion begins with the assumption that things, their use, their valuation, and their appeal are not something added to a religion, but rather inextricable from it'. In line with the embracing posture of the field, these scholars argue that this turn in religious studies also focuses on 'what things and bodies do' (Meyer et al. 2010:209), with the view to produce an epistemic and aesthetic paradigm that seeks to make sense of the sacred as social reality. Their coupling of things with the body, insists on the necessary relationship between the material and embodied or sensory engagements with the material. For them ' $[a]$ body consists of viscera, skeleton, musculature, and flesh, but also brain/mind, sensation, imagination, cognition, and the interface with the worlds around and within the body' (Meyer et al. 2010:209), while things are the objects that the body apprehends. 
For them, things are symbols of the social body and they reflect 'material economy at work in sacred things such as relics and books and icons' (Meyer et al. 2010:209).

In his reflection on the sacred life of things, Graham Harvey (2014) offers a changing notion of animism and suggests that animism becomes more than a belief that objects possess sacred power, but instead that it should be regarded as a set of procedures or relations between objects, humans, and other beings that ultimately endow agency on both the human and non-human (Harvey 2014). As such, 'things' placed in relation to each other (whether intentionally or otherwise), are able to produce an enabling environment for the social actors and for the artefact. In this way the bodily or sensory reception of the objects releases its productive power.

David Morgan (2010) suggests that material religion introduces a welcome departure from the notion of religion as worldview or system of belief, and that frees scholars and religious actors from the dominance of institutional religion and makes possible an appreciation of everyday objects and practices. Morgan's shift from what the object means to what the object does, draws the attention to the social life and presence of the object. This is a call to turn from a focus on beliefs and institutions to the social life of things in processes and techniques of religious practice - the ways that things assume sacred meaning interacts with and within a social environment. What emerges from the literature reviewed above is that the objects and the embodied reception of these objects, suggest that material things possess agentic potential to activate and transform meaning in the everyday life of the believers, and to disrupt the dominance of the institution.

\section{The sacred life of things:}

\section{Race and material religion in South Africa}

Religious studies have historically been concerned with belief and its relation to ritual and institutions of belief or non-belief - also in South Africa. However, as I have suggested above, when we apply Chidester's work on religion and fetish in colonial and postcolonial South Africa, with Dlamini's sensory nostalgia and Chance's elemental framing of the social political environment, African traditional religion emerges as a disruptive category in religious 


\section{Federico G. Settler}

studies as well as in the socio-political life in South Africa. What these three authors demonstrate is the various ways that religion bleeds into the everyday life through the deployment of things - everyday artefacts - as well as the embodied experience of those things that give account of the sacred.

As indicated in the introduction of this article, religion scholars, commentators, and policy makers in the past few years in South Africa have been concerned with the use of everyday material in religious ceremonies, the production of new economies of religion, and the regulation of and responsibility over seemingly new religious movements in South Africa. The coming to prominence of several supposedly new religious movements in this country and the figure popularly known as Pastor Mboro, alongside other similar religious actors, continue to fascinate everybody with their ability to entice the religious and agreeable, though not necessarily vulnerable or gullible people, through material and embodied engagement with religion (Kgatle 2017; Maluleke 2014). This offers the opportunity to not simply produce an analysis of media or legal articulations and contestations of these new religious movements (Frahm-Arp 2015), but to focus on the lived experience - the embodied realities of believers and the religious life of objects as discourses of the sacred in everyday life.

Mboro and other religious actors like him are not a new phenomenon in South Africa, as suggested by some scholars who label them as new religious movements (Kgatle 2017). These new brands of Christian churches and institutions can be regarded as a contemporary manifestation of religious beliefs and practices that has previously existed in other forms, for example, it has for some time been quite common in South Africa to meet a vendor on the street that would hand passers-by a pamphlet offering a schedule of diagnostic and healing services by a designated religious leader (Mokgobi 2012). They generally claim abilities to diagnose and remedy both spiritual and material problems, often explicitly relying on the belief that there are religious and cultural solutions to the material and embodied problems that people experience. Similarly, within African traditional religion, it is precisely through the formal consultation of a sacred specialist - an inyanga or sangoma - that religious people seek both diagnostic and remedial services in exchange for a fee or tribute. It is for this reason that I suggest that the religious phenomenon of diagnosis and remedy, using everyday artefacts or plants, are not new within the broader religious context of South Africa. It is perhaps new, because these are Christian churches who use the material and the embodied 
reception as the locus of their religious work and practices, and through which they contest and assert boundaries over what counts as sacred. It is for this reason that I propose that for a meaningful discussion on material religion in South Africa, one must recognize that the contests over sacred things and the embodied reception of these things are often, if not always, based on race and gender.

\section{The religious life of things}

Since Appadurai's seminal text, The social life of things, there was an increasing interest in the study of the social life (Appadurai 2006; Morgan 2009; Jenkins 2014) or the afterlife of things (Fennetaux, Junqua \& Vasset 2014) - specifically in South Africa. Appadurai (1988) in particular points out that it has become commonplace in the politics of exchange between the imperial center and the colonial periphery that various commodities such as masks, spices, and blankets become sources of exchange, and that this also marks an exchange of value and meaning. Other than Chidester, Dlamini, and Chance with their use of the fetish, the sensory, and the elemental, the study of things have manifested in a varied interest in uniforms such as clothes, formal uniforms, and regalia. In Bruce Lincoln's book, Discourse and the construction of society (Lincoln 2014), the uniformed colonist becomes incorporated into the annual fertility ritual concerned with reinforcing the power and authority of the Swazi king. Achille Mbembe (2001), though not a religion scholar, recognizes that the symbolic function of the military uniform in postcolonial Africa is a powerful trope associated with colonial and postcolonial violence against black people. Similarly, Haddad (2004) examines the African Methodist women's (manyano) religious association with their uniform and suggests that the uniform of the manyano - representing mothering as it did - offers black women symbolic resources to construct mothering as survival and resistance to the violent mobilizations in the late apartheid period. For Nthabiseng Motsemme (2004) the same uniform also emerges an as 'alternative sanctuary' from the violence done to women every day.

The question may be asked why I am indulging this side-discussion about uniforms in the African religious context. Although this discussion is not new, it helps to make two points: First, that a context of epistemic violence that accompanies or surrounds the black religious experience, is often dismissed, 


\section{Federico G. Settler}

excluded, vilified, or infantilized as superstition, and second, despite this history of exclusion and regulation of religion, Graham Harvey (2005:37), in his book, Animism: Respecting the living world, argues that some stones are just stones, and other stones are more than just stones. What this points to is that the contestation on how things get to possess religious meaning and are able to be endowed with religious meaning and authority, continues to persist in contemporary South Africa.

An examination of the CRL Commission Report of 2017 not only reveals a public discomfort with the new forms of religion offered and practices advocated by religious actors like Motsoeneng, Daniel, and Mnguni, but it also signals an appetite for their particular brand of religious techniques and practices. Ultimately, their use, invocation, and deployment of everyday material artefacts in their religious work, while not uncommon to Southern Africa, is nonetheless at the heart of a public outcry against these religious practices. The CRL Rights Commission (2017:31) notes a range of everyday things, including prayer towels, ATMs, oils, stickers, and other amulets deployed in religious work as well as in the media, making congregants consume grass, drink petrol, semen, or soap, eating and using snakes in church, removing women's underwear, the use of belts and caning sticks on the possessed, and the spraying of Doom (insecticide) on congregants.

Further, what adds to the general discomfort regarding these religious practices, is that they occur outside regular religious calendars and sacred sites and produce new cartographies of the sacred. Notwithstanding the ethics related to the authority and claims about abuse of power in these new, or notso-new religious movements, the social life of things in these churches or movements relies on and unleashes the material on various levels. While the artefact or thing is for sale as a commodity (for example, Mboro's heavenly pictures), that allows the believer to enjoy proximity to the religious leader or the sacred community, while the thing also serves as a protective talisman or device that would bring good fortune.

However, the problems with seeking to regulate a material expression of religion located in the everyday life is that the use of artefacts and their meaning could change, and new objects are likely to be introduced. Much of the critique of the CRL Commission and the public appears to rest on the very material activation of everyday objects like rocks, insecticide, and handkerchiefs as legitimate religious instruments and as possessing religious capital. Generally, the use of authorized materials such as oils, prayer towels, 
holy water, candles, and incense are accepted, because these religious artefacts are believed to have been theologically justified (Clarke \& Beyer 2009; Parsons 2006), and yet the use of other everyday objects has provoked widespread anxieties over what objects count as sacred, which ultimately raises questions over the classification of religious objects, beliefs, and behaviors (Masuzawa 2005; King 1999).

While this anxiety over the sacred manifests or is articulated as concern for the gullible and exploited, poor believers (Chimuka 2018), we ought to nonetheless interrogate the discriminations between materialization of the sacred in local African contexts,

- where new and contested everyday objects are activated and endowed with religious and sacred meaning;

- where new actors, often non-experts, assume visibility and are endowed with the authority and sovereignty over religious communities;

- where new avenues towards material and spiritual fulfilment are being created.

The public, political, and legal contestations over the use of everyday or household things in religious work among new religious actors have been discussed above. In 2016, Zimbabwean media reports that Prophet Tapiwa Freddy has claimed to have anointed soap, blessed by special angles, and that 'God will be doing things through the anointed soaps' (Dachen 2016). The BBC News (2016) reports that in neighboring South Africa, '[t]he country has seen a wave of practices where church members have been subjected to unorthodox rituals to receive healing' after self-proclaimed religious leader, Lethebo Rabalago, sprayed his congregants with Doom and claimed that it can heal people. Similarly, in 2016, Prophet Rufus Phala from the Limpopo Province convinced his church members to drink Dettol, an antiseptic liquid soap, as a way to cure illnesses and ailments (Motau 2016).

While the ethics of compelling religious followers to do something they might otherwise regard as harmful, is not dismissed, I am also not particularly concerned with contesting the truth-claims related to these events. However, I am curious about the fact that all these religious leaders draw on everyday artefacts to generate an aura of sacrality or intimate connection with the divine. Unlike the more publicized reports about pastors getting their 


\section{Federico G. Settler}

congregants to eat grass or snakes and rocks (transubstantiation), the invocation and activation of everyday items such as motor oil, fuel, detergents, insecticides, and soap are all endowed with sacred potential to protect, heal, and restore the believer. Each of these artefacts has a particular commercial and social history - the social life of things - as a commodity that assumes a range of values that are simultaneously material, commercial, and religious. Anne McClintock notes in her book, Imperial leather, that in the social history of soap, Africans have been subjected to the civilizing mission of cotton and soap to be covered and cleansed (McClintock 1995:31). While, as McClintock (1995:33) argues, 'soap and cleaning rituals became central to the demarcation of body boundaries and the policing of social hierarchies', in these religious movements soap has become central to what constitutes religion. Prophet Freddy and Prophet Phala variously rely on their congregants, drawing on alternatives to register the meaning-making that is more aligned with indigenous religion than with Christian normative practices. Having been blessed by special angels, Pastor Freddy's soap, used in a regular way, is believed to possess healing properties with both bodily restoration and harmonious relations with one's partners (a woman will be fertile and will find a husband). While it is easy to dismiss these claims and adherences as ludicrous or childish, it is not uncommon in indigenous religion, for example, for sacred specialists to utilize everyday things, such as pottery fragments, bones, glass, shells, or driftwood (Insoll, 2011; White 2015) to diagnose, and divine issues of personal or social discord or physical discomfort. The brand of religious work by Phala and Freddy is more consistent with the sacred specialists in African traditional or black religion, despite their self-identification as Christians.

Why therefore the huge public outcry and the government urgency to regulate these new religious movements and force them into a normative of what constitutes religion? There is a number of problems with both public and state compulsion to regulate religious associations and to protect gullible believers from exploitation. This is for many people an ethical concern, but with respect to the use of everyday 'things' in African social contexts, it creates new tensions and expands the concept of what might be regarded as religion through activating or invoking the agentic potential of everyday things; it asserts a new archaeology and taxonomy of religious objects premised on the need to incorporate and take seriously African or black religious ways of knowing and being, and not to simply dismiss it as naivety or exploitation/ 
abuse of religious beliefs; it requires suitable, indigenous methodologies for making intelligible these (new) invocations of the sacred in everyday things, instead of contesting, dismissing, and excluding or regulating these materializations of religion, as they spill into the postcolonial public domain.

In a postcolonial African context, religious actors increasingly invoke everyday objects for simultaneously multiple purposes related to demarcating, asserting, and resisting competing conceptions of religion. As such we may provisionally conclude that the religious activation of everyday things is disruptive but productive; provocative but deliberative; and ultimately decolonial - in that it disrupts the knowledge and power matrix in religion and postcolonial, because it draws on available, though contested, imperial taxonomies, archives, and artefacts to assert new meaning.

\section{The black body in sensory and material landscapes}

Traditionally, the sociology of religion has been concerned with the study of ritual as embodied engagements with institutions of religion, and in this the senses have been perceived as an aspect of the corporeal. Invoking Maurice Merleau-Ponty, Abercrombie, Hill and Turner (2006:127) state that 'the body is simultaneously an object that can be observed and a mode of being...that makes that observation possible'. Having developed this thesis about the intimacy between human bodies and their reception in the everyday experience, they conclude that embodiment is fundamentally a process of apprehension and perception. It is therefore not surprising that in the context of material religion, Houtman and Meyer (2012) have argued for a progression from an initial interest in a material or visual culture (reception of objects), towards the study of the body within social and cultural contexts, and the more recent exploration of the senses.

The idea of the body in its social and historical context is hauntingly elaborated by Harvard historian, Walter Johnson (2013), in his book, River of dark dreams, where he suggests that to understand the black experience, one needs to focus on the ecology of the enslaved - the ecology of the everyday wherein (black) bodies were regulated, carted, ordered, and whipped basically governed. He further clarifies the idea of the black body as commodity by referring to the most rudimentary, biological aspects of plantation life which he terms 'bare-life processes and material exchanges' - 


\section{Federico G. Settler}

the sun and soil, semen and faeces, blood and milk. These are brought into sharp focus within the history of 'slavery' and 'capitalism' (Johnson 2013:9).

If, as Johnson (2013:162) suggests that black existence is calculated and imagined in terms of the plantation ecology and economy, could we then not suggest that black religion or religious experiences emerge out of social histories, populated with regimes and rhythms that define the black body and experience through alienation, terror, incarceration, and death? In this regard, I find Dlamini's sensory exploration of the black struggle in South Africa just as helpful as Chance's, placing the body in a social context through exploring the elements. Chance (2018:21ff, 145) argues that black lives in South Africa are defined by contestation over water (amanzi), clean air (umoya), fire (umlilo), and land (umhlaba). It would be disingenuous to argue that the religious actors in the abovementioned new religious movements are not aware of the social conditions in which their congregants live. Maluleke (2014) argues that for the religious leaders and adherents, these acts are symbolic efforts concerned with access to the transcendent, or an experience of the sacred that may offer relief from the material conditions of life, or the nurturing of an alternative, imagined future. In early 2018, Pastor Mboro offered to pray for people that their land might be restored to them, and that those without homes would have houses to live in (Zeeman 2018).

During recent years, many congregants offered their bodies for an experience of the sacred, for the remedy of an ailment, or as a declaration of faith (Mathunjwa 2017). While the CRL commission rightfully expresses concern about the possible physical and health risks to religious adherents presented by some of these supposedly religious acts, what is of interest is that offering one's body is here regarded as gullibility and naivety, and deserving of state intervention. When Hindu yogis, for example, roll their body on the road from city to city, it is generally accepted to be a pilgrimage or sacred quest (Around the world in 800 days 2016), or when religious devotees push their bodies to the limit by walking on hot coals or machetes, or scar their bodies in a religious quest, it is celebrated as a sign of devotion (David 2009). Yet these supposedly neo-pentecostal churches' use of everyday artefacts in religious quests and rituals are framed as exploitation by the religious experts, and gullibility by the religious followers (Kgatle 2017; Chimuka 2018).

In the elaboration of its brief, the CRL Commission saw, among others, as its responsibility the task to 'understand the deep societal thinking that makes some members of our society vulnerable and gullible on views 
expressed and actions during religious ceremonies' (CRL Rights Commission 2017:6). While this position reveals a colonial perspective on African religion or religious contexts, likely to result in the gullible grabbing of any fetish or superstition, it dismisses the agentic dimension and indigenous orientation of an embodied religion in these situations. The CRL Commission's use of terms such as 'experts' and bona fide 'religious practitioners' (CRL Rights Commission 2017:1, 43), expose a possible bias against black or indigenous religious institutions, beliefs, and practices. One can therefore conclude that this need for a greater regulation that actually betrays the poor black people, is based on the fact that these practices are religiously unacceptable and that the embodied experience and the material in black religious practices are not constituted as legitimately religious. I therefore argue that the introduction of everyday material objects into religious ceremonies first necessitates an expanded idea about what constitutes religion, and what can be defined as Christian religious practices, and second, the need for an expanded register related to what objects and embodied experiences can be regarded as legitimate.

If one is to follow the arguments of the CRL Commission that the use of everyday objects and embodied religious experiences are exploitation, then we risk agreeing that black religious bodies require greater regulation. This can be likened to Walter Johnson's plantation ecology of everyday life, where black bodies are controlled through regulating them every minute, and in every mundane aspect of life - when to sleep, when to eat, when and where to have sex, who to have sex with, how much water to drink, what to eat, and where to sleep. This implies that black people cannot be trusted to determine what artefacts and what embodied experiences they wish to participate in and invoke as religious.

\section{Conclusion}

In the documents of recent scholars on material religion - locally and abroad one struggles to find an engagement with the body and the senses that is not almost entirely deracialized. Material religion claims to be concerned with not just objects, but also with the body in its social context. Our engagement with material religion in an African religious context must therefore, by necessity, 


\section{Federico G. Settler}

engage the imperial histories related to both religion and the objects deployed by religious actors. Similarly, the embodied and sensory experience of religious materials cannot be dehistoricized or deracialized because, as I have argued above, when a religion is practiced in Africa, or when a religious ritual finds a parallel expression in African religious contexts, it is easily dismissed as superstition or functionalist fabrications aimed at abusing and exploiting the believers.

Chidester, like Dlamini and Chance, offers the scholar of religion ways to explain and give account of the emergence of new religions without dismissing the ethical and theological challenges that these may pose. While Chidester's work on the material or social artefact offers a wide range of religious meanings, it nonetheless translates into a superficial treatment of the embodied and sensory system in a postcolonial environment. What do the acts of Dlamini's cockroaches - as symbols of plenty - and Pastor Rabalago's Doom spraying mean for religion and materiality in a postcolonial South Africa? It suggests that people are drawing on artefacts and meaning that exist in their social context and deploy it through their embodied and sensory systems to produce imaginative discourses of the sacred. Material religion in an African social context is serious about indigenous or local ways of knowing and being and renders as meaningful the notion that in this social context, people smell differently, see the world differently, imagine different horizons, and feel and move in it differently. The task of the scholar of religion is to interpret the local meaning and uses of everyday things and to interrogate (not judge) the deployment of the body, the senses, and elements in narratives of meaning related to the sacred.

\section{References}

Abercrombie, N., S. Hill \& B.S. Turner 2006. Dictionary of Sociology. 5th ed. London: Penguin Books Ltd.

Appadurai, A. 1988. The social life of things: Commodities in cultural perspective. Cambridge: Cambridge University Press.

Appadurai, A. 2006. The thing itself. Public Culture 18, 1: 15-21. 
Around the world in 800 days. 2016. Going down the spiritual road. Available at: https://www.aroundtheworldin800days.com/blog/going-down-thespiritual-road. (Accessed on 4 April 2018.)

Barad, K. 2007. Meeting the universe halfway: Quantum physics and the entanglement of matter and meaning. Durham: Duke University Press.

BBC News. 2016. South Africa's 'Prophet of Doom' condemned. 21 November 2016. Available at: https://www.bbc.com/news/world-africa38051923. (Accessed on 4 August 2018.)

Braidotti, R. 2002. Metamorphoses: Towards a materialist theory of becoming. Cambridge: Polity Press.

Chance, K. 2018. Living politics in South Africa's urban shacklands. Chicago: Chicago University Press.

Chidester, D. 1991. Shots in the street. Boston: Beacon Press.

Chidester, D. 1996. Savage systems. Charlottesville: University of Virginia Press.

Chidester, D. 2000. Christianity: A global history. New York: HarperCollins.

Chidester, D. 2012. Wild religion. Berkeley: University of California Press.

Chidester, D. 2018. Religion: Material dynamics. Berkeley: University of California Press.

Chimuka, T.A. 2018. The threat of gullibility: Faith and Christian behaviour in Southern Africa. Oral History Journal of South Africa 5, 1: 55-70.

Clarke, P.B. \& P. Beyer 2009. The world's religions: Continuities and transformations. Abingdon: Routledge.

CRL Rights Commission. 2017. Report of the hearings on commercialisation of religion and the abuse of people's belief systems. Available at: http://www.crlcommission.org.za/docs/Report\%200n\%20Commeciali zation\%20of\%20Religion\%20and\%20Abuse\%20of\%20People $\% 27 \mathrm{~s} \%$ 20Believe\%20Systems\%20final.pdf. (Accessed on 4 August 2018.)

Dachen, I. 2016. Zimbabwe prophet launches anointed soap that lures men, bring back lost lovers. Pulse News, 14 April 2016. Available at https://www.pulse.ng/gist/in-gods-name-zimbabwe-prophet-launchesanointed-soap-that-lures-men-bring-back-lost-lovers-id4919487.html. (Accessed on 4 August 2018.)

David, A. 2009. Performing for the gods? Dance and embodied ritual in British Hindu temples. South Asian Popular Culture 7, 3: 217-231.

Dlamini, J. 2009. Native nostalgia. Auckland Park, Johannesburg: Jacana Media. 
Fennetaux, A., A. Junqua, \& S. Vasset (eds.) 2014. The afterlife of used things. New York: Routledge.

Frahm-Arp, M. 2015. Dr Maria Frahm-Arp on some church miracles. SABC Interview, 19 July 2015. YouTube. Available at: https://www.you tube.com/watch? $\mathrm{v}=$ dhnj-qEHmNY. (Accessed on 4 August 2018.)

Haddad, B. 2004. The Manyano movement in South Africa: Site of struggle, survival and resistance. Agenda 61: 4-13.

Harvey, G. 2005. Animism: Respecting the living world. New York: Columbia University Press.

Harvey, G. 2014. The handbook of contemporary animism. Oxon: Routledge.

Houtman, D. \& B. Meyer 2012. Things: Religion and the question of materiality. New York: Fordham University Press.

Insoll, T. 2011. Introduction. Shrines, substances and medicine in sub-Saharan Africa: Archaeological, anthropological, and historical perspectives. Anthropology \& Medicine 18, 2: 145-166.

Jenkins, R. 2014. Social identity. New York: Routledge.

Jethro, D.H. 2014. Vuvuzela magic: The production and consumption of African cultural heritage during the FIFA 2010 World Cup. African Diaspora 7: 177-204.

Johnson, W. 2013. River of dark dreams. Cambridge: Harvard University Press.

Kgatle, M.S. 2017. The unusual practices within some neo-pentecostal churches in South Africa: Reflections and recommendations. HTS Teologiese Studies/Theological Studies 73, 3: 8 pages. DOI: https:// doi.org/10.4102/hts.v73i3.4656

King, R. 1999. Orientalism and religion. New York: Routledge.

Lincoln, B. 2014. Discourse and the construction of society: Comparative studies of myth, ritual and classification. $2^{\text {nd }}$ ed. New York: Oxford University Press.

Maluleke, T.S. 2014. The prophet syndrome: Let them eat grass. Mail and Guardian, 24 October 2014. Available at: https://mg.co.za/article/201410-23-the-prophet-syndrome-let-them-eat-grass. (Accessed on 24 July 2018.)

Maluleke, T.S. 2015. Between Pretoria and George Goch hostel: God in South Africa. New Agenda 59: 35-39. Available at: https://journals.co.za/ content/nagenda/2015/59/EJC178736. (Accessed on 24 July 2018.) 
Masuzawa, T. 2005. The invention of world religions. Chicago: Chicago University Press.

Mathunjwa, Z. 2017. Spraying Doom in the house of the Lord: The struggle to regulate SA's churches. Huffpost: Lifestyle, 17 August 2017. Available at: https://www.huffingtonpost.co.za/2017/08/17/spraying-doom-inthe-house-of-the-lord-the-struggle-to-regulate_a_23080296/. (Accessed on 20 April 2018.)

Mbembe, A. 2001. On the postcolony. Berkeley: University of California Press.

McClintock, A. 1995. Imperial leather. New York: Routledge.

Meyer, B. 2008. Materializing religion. Material Religion 4, 2: 227.

Meyer B., D. Morgan, C. Paine \& B. Plate 2010. The origin and mission of material religion. Religion 40, 3: 207-211.

Mokgobi, M.G. 2012. Views on traditional healing: Implications for integration of traditional healing and Western medicine in South Africa. PhD Thesis, University of South Africa, Pretoria.

Molobi, S. 2017. Pastor's lawyer a fake! Daily Sun, 27 June 2017. Available at: https://www.dailysun.co.za/News/National/pastors-lawyer-a-fake20170627. (Accessed on 4 August 2017.)

Morgan, D. 2009. The space between intimates and strangers. Milton Keynes: Open University Press.

Morgan, D. 2010. Religion and material culture: The matter of belief. New York: Routledge.

Morgan, D. 2012. The look of the sacred. In Orsi, R.A. (ed.): Cambridge companion to religious studies. New York: Cambridge University Press.

Motsemme, N. 2004. The mute always speak: On women's silences at the Truth and Reconciliation Commission. Current Sociology 52, 5: 909932.

Motau, K. 2016. Limpopo pastor gives congregants Dettol to drink. Eyewitness News, 9 December 2016. Available at: https://ewn.co.za/2016/12/09/ limpopo-pastor-gives-congre-gants-miracle-dettol-to-drink. (Accessed on 4 August 2018.)

Parsons, T. 2006. The theoretical development of the sociology of religion: A chapter in the history of modern social science. In Kunin, S.D. (ed.): Theories of religion: A reader. New Brunswick: Rutgers University Press. 
News24. 2014. SA pastor under fire over grass-eating followers. 13 January 2014. Available at: https://www.news24.com/SouthAfrica/ News/SApastor-under-fire-over-grass-eating-followers-20140113. (Accessed on 24 July 2018.)

Strijdom, J.M. 2014. The material turn in religious studies and the possibility of critique: Assessing Chidester's analysis of 'the fetish'. HTS Teologiese Studies/Theological Studies 70, 1: 7 pages. Art. \#2116. DOI: http://dx.doi.org/10.4102/hts.v70i1.2116

Sweet, M. 2002. Inventing the Victorians. London: Faber \& Faber.

Thornhill, T. 2014. First he had his congregation eating grass to make them 'close to God', now controversial South African preacher makes his flock drink PETROL. MailOnline, 15 October 2014. Available at: https://www.dailymail.co.uk/news/article-2794275/first-congregationeating-grass-make-close-god-controversial-south-african-preachermakes-flock-drink-petrol.html. (Accessed on 4 August 2018.)

Van den Toren, B. 2015. African neo-pentecostalism in the face of secularization: Problems and possibilities. Cairo Journal of Theology 2, 1: 103-120.

White, P. 2015. The concept of diseases and health care in African traditional religion in Ghana. HTS Teologiese Studies/Theological Studies 71, 3: 7 pages. Art. \#2762. DOI: http://dx.doi.org/10.4102/hts.v71i3.2762

Zeeman, K. 2018. Pastor Mboro believes he can 'help you get the land back'. Sunday Times: Times Live, 18 April 2018. Available at: https://www.timeslive.co.za/tshisa-live/tshisa-live/2018-04-18-pastormboro-believes-he-can-help-you-get-the-land-back/. (Accessed on 20 April 2018.)

Federico Settler School of Religion, Philosophy \& Classics University of KwaZulu-Natal settler@ukzn.ac.za 